УДК 32:504

https://doi.org/10.34142/24130060.2019.19.2.03

\title{
ДИВЕРГЕНЦІЇ ЕКОЛОГІЧНОГО РУХУ (ЕКОЛОГІЧНИЙ РАДИКАЛІЗМ ТА ЕКОЛОГІЧНИЙ ТЕРОРИЗМ) КРІЗЬ ПРИЗМУ ПОЛІТОЛОГІЧНОГО ВИМІРУ
}

\author{
Ю.І. Калюжна \\ Харківський національний педагогічний університет імені Г.С. Сковороди
}

У статті здійснена спроба теоретичного аналізу суспільно-політичного явища «екологічний тероризм». Комплекс глобальних екологічних проблем XXI століття корелює з радикалізачією екологічних настроїв, - у боротьбі за вирішення екологічних проблем, за право кожної людини на чисте довкілля і справедливий розподіл ресурсів - відбувається трансформачія екологічних поглядів у бік екстремізму та радикалізму, а відтак, все часті екоактивісти перетинають межу загальносвітового абсолюту «цінності людського життя», - $і$ стають екотерористами.

Автором статті наголошується, в сучасному науковому просторі відчутний дефіциит дослідницького матеріалу, щзодо проблематики екологічного тероризму, щзо значно ускладнює теоретичні розвідки та пошук методологічного інструментарію до розуміння даного суспільно-політичного явища. $У$ пошуках ключів до розуміння «екологічного тероризму» автор звертається до еволючії екологічного руху (яка відбувалась за двома основними траєкторіями: інституцฺіалізація екологічного руху та політизачія екологічного руху) та фіксує, щьо на певному етапі еволючійного розвитку екологічного руху виникають дивергениії, у вигляді екстремізму та радикалізації екологічного руху, які й стали підгрунтям екологічного тероризму. Теоретичний аналіз діяльність екологічних терористичних організацій дозволяе стверджувати: наростаючі відчуття тривоги, безпорадності та неминучості настання екологічної катастрофи планетарного масштабу, тотальне розчарування в політичних інститутах та діяльності міжнародних екологічних організачій, «псевдонаукові вірування, божевільний популізм, застарілі та нові групові фобії в істеризованих спільнотах перетворюється на теоретичне підгрунтя та рушії насильства», а отже, стають «поживною речовиною»для екологічного тероризму.

Ключові слова: екологічний рух, екологічні проблеми, екологічна політика, глобальна екологічна криза, екстремізм $і$ радикалізм, екологічний тероризм, ризики сучасності.

\section{ДИВЕРГЕНЦИИ ЭКОЛОГИЧЕСКОГО ДВИЖЕНИЯ (ЭКОЛОГИЧЕСКИЙ РАДИКАЛИЗМ И ЭКОЛОГИЧЕСКИЙ ТЕРРОРИЗМ) ЧЕРЕЗ ПРИЗМУ ПОЛИТОЛОГИЧЕСКОГО ИЗМЕРЕНИЯ}

\section{Ю.И. Калюжная}

В статье осуществляется попьтка теоретического анализа общественнополитического явления «экологический терроризм». Комплекс глобальных экологических проблем XXI века коррелирует с радикализацией экологических взглядов, - в борьбе за 
решение экологических проблем, право каждого человека на чистую окружающую среду и справедливое распределение ресурсов - экологические взгляды трансформируются в сторону экстремизма и радикализма, потому, всё чаще экоактивисты переходять гранииу общечеловеческого абсолюта «иенности человеческой жизни», - и становятся экотеррористами.

Автором статьи акцентируется, в современном научном пространстве существует дефицит исследовательского материала, относительно проблематики экологического терроризма, что значительно усложняет теоретические разведки и поиск методологического инструментария $\kappa$ пониманию данного общественнополитического явления. В поисках ключей к пониманию «экологического терроризма» автор обращчается к эволючии экологического движения (которая проходила по двум основним траекториям: институциализация экологического движения и политизация экологического движения) и фиксирует, что на определённом этапе эволюиионного развития происходят дивергенции, в виде экстремизма и радикализма экологического движения, которые и стали основанием экологического терроризма. Теоретический анализ деятельности экологических террористических организаций позволяет утверждать: нарастающие чувства тревоги, беспомощности и неизбежности экологической катастрофы планетарного масштаба, тотальное разочарование $в$ политических институтах и деятельности международных экологических организаций, «псевдонаучные верования, сумасшедший популизм, устаревшие и новые групповые фобии в истеризованых общностях превращаются в теоретическое основание и генераторы насилия», становятся «питательной средой» - для экологического терроризма.

Ключевые слова: экологическое движение, экологические проблемы, экологическая политика, глобальный экологический кризис, экстремизм и радикализм, экологический терроризм, риски современности.

\section{THE WRONG DIRECTIONS OF THE ENVIRONMENTAL MOVEMENT (ENVIRONMENTAL RADICALISM AND ENVIRONMENTAL TERRORISM) FROM A POSITION OF POLITICAL SCIENCE}

\section{J. Kalyuzhna}

The article attempts to analyze theoretically the socio-political phenomenon of «environmental terrorism». Complex of global environmental problems (pollution of air, water, soil, common planetary temperature increase, greenhouse effect, destruction of the ozone layer, large-scale floods, droughts, hurricanes, reduction of biological diversity, scarcity of natural resources, rapid demographic growth, cities crisis, environmental refugees, anthropogenic (man-made) garbage collapse, etc.) correlates with the radicalization of environmental views and the rhetoric of peaceful meetings and pickets of government institutions, corporations and international organizations are being replaced by firing from firearms, laying bombs, arson, namely terrorist acts. In today's world conditions, in the fight for environmental issues solutions, for the right of every person to a clean environment and a fair distribution of resources, environmental views are transformed increasingly into extremism and radicalism, and thus, ecoactivists cross the border and become eco-terrorists.

The author of the article emphasizes that in the modern scientific space there is a significant lack of research material on the issues of environmental terrorism, which significantly complicates theoretical studying and the search for methodological tools for understanding this socio-political phenomenon. In his search for the keys to understanding of "environmental terrorism», the author turns to the evolution of the environmental movement (which has been developing along two main directions: the institutionalization of the environmental movement and the politicization of the environmental movement) and notes that at 
some stage of the evolutionary development of the ecological movement, divergences arise in the form of extremism and radicalism of environmental movements, which became the basis of environmental terrorism. Theoretical analysis of the activities of environmental terrorist organizations, including the Deep Green Resistance, the Huntingdon Society for the Suppression of Cruelty to Animals (Stop Huntingdon Animal Cruelty), the Animal Liberation Front (Animal Liberation Front) and the Earth Liberation Front (Earth Liberation Front), also Earth Above All, Sea Shepherds and others, allows to assert that the increasing feelings of anxiety, helplessness and inevitability of ecological catastrophe on a planetary scale, total disappointment in political institutes and activities of international environmental organizations, "false news and rumors, pseudoscientific beliefs, turned into myths, mad populism, outdated and new group phobias, extremism and all this in hysterically transformational communities is turned into a theoretical basis and a trigger for violence» and becomes «nutritious» substance for the environmental terrorism.

Key words: environmental movement, environmental problems, environmental policy, global environmental crisis, extremism and radicalism, environmental terrorism, the risks of today.

Постановка проблеми. Комплекс глобальних екологічних проблем, забруднення повітря, води, грунтів, загальнопланетарне підвищення температури, парниковий ефект, руйнування озонового шару, масштабні природні катаклізми (повені, посухи, урагани), скорочення біологічного різноманіття, дефіцит природних ресурсів, стрімкий демографічний приріст, «криза міст», збільшення територій непридатних для життя, нестача питної води та продовольства, екологічні біженці, сміттєвий колапс та інше - в цілому дозволяє стверджувати, - антропогенний вплив Сучасної цивілізації на навколишнє середовище провокує настання Глобальної Екологічної Кризи XXI століття, - «Практично все що ми робимо, наносить шкоду біосфері, навколишнє середовище стає все менш стабільним та сприятливим, а наше майбутнє в довгостроковій перспективі - все більш туманним» (Уилсон, 2017, с. 10). Наростаючі відчуття тривоги, безпорадності та неминучості настання екологічної катастрофи планетарного масштабу, тотальне розчарування в політичних інститутах та діяльності міжнародних екологічних організацій, «фальшиві новини і чутки, псевдонаукові вірування, перетворені на міфи, божевільний популізм, застарілі та нові групові фобії все в істеризованих трансформаційних спільнотах перетворюється на теоретичне підгрунтя та рушії насильства» (Костюченко, 2019) і стають «поживною речовиною» для екологічного тероризму. 
Аналіз актуальних досліджень. В вітчизняному наукову просторі відчутний дефіцит дослідницького матеріалу з проблематики «екологічного тероризму», проте відзначимо теоретичні розвідки - В. Андреева, О. Бондар, Н. Заїки, А. Качінського, О. Колбасова, Ю. Костюченко, О. Машкова, Т. Перга, А. Приходченко, Г. Хміль. Експертні оцінки представників західної науки, щодо екологічного тероризму, представлені дослідницькими проектами - П. Глейка, М. Крайтона, Д. Ліддіка, Д. Прескітт, Дж. Ді Рівера, Д. Шварца, Т. Шеффілда, К. Шлейсснера та ін.

Мета статті - полягає у спробі теоретичного аналізу дивергенцій екологічного руху, які зумовили радикалізм і екстремізм екологічних поглядів, та визначити суспільно-політичні фактори, що стали підгрунтям «екологічного тероризму».

Виклад основного матеріалу. Основними траєкторіями еволюції екологічного руху є інституціалізація та політизація:

1) інституцуіалізація екологічного руху: починаючи з 60-70 років $\mathrm{XX}$ століття в суспільстві відбувається усвідомлення відповідальності за екологічне майбутнє Людства, так завдяки зусиллям екоактивістів та громадськості екологічний рух набуває інституційного оформлення створення громадсько-екологічних організацій, робота яких спрямована на консолідацію громадськості задля вирішення проблем довкілля: збереження біологічного різноманіття, створення природоохоронних територій, проведення екологічних експертних оцінок, здійснення екологічного моніторингу, просвітніх проектів, екологічних акціях тощо. Інституціалізація екологічного руху - це шлях від малочисельних груп екоактивістів, які вирішували екологічні проблеми місцевого рівня до міжнародних організацій, діяльність яких спрямована на розв’язання глобальних екологічних проблем, міжнародний характер яких дозволяє успішно просувати низку проектів, зокрема, запровадження ринку квот на шкідливі промислові викиди, скорочення ядерної енергетики, перехід на біопаливо та альтернативні джерела електроенергії, застосування ресурсозберігаючих 
технологій, вдосконалення системи переробки сміття, маркування харчової продукції тощо. Найбільш відомими міжнародними громадськими екологічними організаціями є: Конференція ООН 3 навколишнього середовища розвитку, Комісія ООН зі сталого розвитку, Світовий центр моніторингу охорони навколишнього середовища, Міжнародна академія довкілля, Світовий союз охорони природи, Світовий фонд дикої природи, Міжнародна організація «Зелений Хрест», Глобальна інформаційна база даних про земельні ресурси, Трест з охорони Землі, Глобальний екологічний фонд та інші.

2) політизація екологічного руху: екологічний рух, що виник 3 соціальних протестів проти ядерного озброєння, війни та «народного голосу» за право жити в «екологічно безпечному світі», розпочав інтеграцію в політичний простір, так, - у березні 1972 року на громадських зборах м. Хобарт (Австралія) була сформована перша в світі екологічна партія «Об’єднана тасманська група», а вже через декілька десятиліть «зелені» зміцнили свої політичні позиції до парламентського та урядового представництва, отже, отримали можливість вирішувати екологічні питання на політичному та законодавчому рівнях; в сучасному світі західних демократій політичні партії екологічного спектру належать до політичних сил загальнонаціонального масштабу, серед найбільш впливових «Свропейська Партія Зелених» (СС), «Спілка 90/Зелені» (Німеччина), «Свропа Екологія Зелені» (Франція), «Зелені Ліві» (Нідерланди), «Зелена Альтернатива» (Австрія), «Зелена Партія Канади» (Канада), «Зелена Спілка» (Фінляндія), «Австралійська Партія Зелених» (Австралія) та багато інших.

Проте, еволюції екологічного руху притаманні дивергенції, у вигляді екстремізму та радикалізації екологічного руху, які стають підгрунтям сучасного суспільно-політичного явища - екологічного тероризму. Згідно 3 П. Глейком екологічний тероризм визначається «як незаконне застосування сили проти екологічних ресурсів чи систем, 3 наміром нанести шкоду окремим особам або позбавити населення екологічних благ в ім'я досягнення 
певної політичної або соціальної мети» (Gleick, 2006), а ключовою відмінністю екологічного тероризму від інших видів тероризму є специфічна ціль першого, якою $є$ навколишнє середовище та ресурси. Українські дослідники О. Машков і Ю. Мамчур (2018, с. 18) визначають екологічний тероризм наступним чином: «це незаконне або умисне заподіяння значної шкоди навколишньому природному середовищу 3 метою залякування населення або примусу уряду або міжнародної організації до здійснення будь-яких дій або утримання від їх вчинення». Тож, спробуємо визначити, чому в сучасному світі у боротьбі за вирішення екологічних проблем, за право кожної людини на чисте довкілля і справедливий розподіл ресурсів все часті, відбувається трансформація екологічних поглядів у бік екстремізму та радикалізму, за яких суспільно-політичних умов, екоактивісти відмовляються від раціонально-легальних інструментів екологічної боротьби (інституціалізація та політизація екологічного руху) та перетинають межу загальносвітового абсолюту «цінності людського життя», і стають екотерористами.

Перший фактор - соціально-психологічний: сучасна реальність як генератор страхів та істеризованості суспільства. За твердженням сучасних дослідників, XXI століття визначається в категоріях - ризиків, тривоги, страху та соціальної істерії - «Соціально-політична нестабільність, постійне зниження рівня життя, збільшення кількості катастроф, стихійних лих і природних катаклізмів тримають сучасну людину в постійному страху $\mathrm{i}$ тривозі. Тривога перед невідомим і непередбачуваним майбутнім глибоко вкорінена в людське мислення. Людей може жахати минуле i не задовольняти сьогодення. Але дійсний страх людина здатна відчувати насамперед тоді, коли думає про те, що чекає іiї в майбутньому (Горохова, 2010, с. 256). Дійсно, свідомість сучасної людини перебуває під постійним комунікативно-інформаційним тиском, щодо масштабну і турбулентності кліматично-екологічних трансформацій: щотижневі новини про повені, посухи, землетруси, урагани, лісові пожежі та інші природні катаклізми; 
«шокуюча статистика» у звітах 3 моніторингу та оцінки стану довкілля, «апокаліптичний стиль» подачі інформації про екологічне майбутнє Землі в 3МI та ін., - за таких умов, в суспільстві відбувається поляризація екологічних настроїв: з одного боку, рутинізація і, навіть апатія, в сприйнятті інформаційних повідомлень екологічної тематики, 3 іншого, - акумулящія страхів, «щуо призводить до невротизації громадської свідомості, стану «екоістерї̈» (Курляк, 2006, с. 37). Зокрема, німецький соціолог У. Бек, у рефлексії щодо сучасного суспільства ризику, фокусуючи увагу на проблемі соціальних страхів визначає провідну роль знання, як детермінанта страху, якщо людині повідомити інформацію про те, що для неї існує загроза, то небезпека для неї виникне, навіть якщо людина їі не відчуває: «У тому, що стосується позитивної чи негативної відповіді, ступеня, масштабу та форм виявлення загрожуючий людині небезпеки, людина принципова залежить від чужого знання. Жертви стають некомпетентними, у справі їх власного життя. Вони втрачають значну частину суверенного знання. Шкідливе, прихована загроза, вороже причаїлось всюди, але розмірковувати над шкодою чи користю самі вони не в змозі і саме тому змушені використовувати гіпотези, методи i контроверзи чужих виробників знання» (Бек, 2000, с. 64). Дозволимо твердження, страх глобальної екологічної катастрофи XXI століття $є$ суспільним екзистенційний страхом - «глибинний страх від усвідомлення своєї смертності, незворотності буття» (Стасюк, 2013, с. 315), який значною мірою сформовано сучасними ЗМI та призводить до екстремізму і радикалізації екологічних поглядів, а у крайніх випадках - до екологічного терору. Акумуляція страхів та істеричні оцінки, щодо перспектив екологічного майбутнього нашої планети стають причиною варварських проявів екологічного тероризму - цитата 3 маніфесту «The Great Replacement» (Велике Заміщення) одного з найбільш відомих екотерористів XXI століття 28-річного Брентона Тарранта: «відбувається бурна урбанізація та індустріалізація, постійно розширюються міста та зменшуються ліси, продовжується повне відсторонення людини від природи 3 очевидними 
результатами. ... навколишнє середовище знищується через перенаселення. ... Вбивайте окупантів. Вбивайте перенаселення i таким чином врятуйте довкілля» (MilneNews, 2019) - 15 березня 2019 року у м. Крайстчерч (Нова Зеландія) Б. Таррант здійснив акт екологічного терору, в результаті якого загинуло 51 людина, 50 поранено; 21-річний Патрік Крузіус своєму маніфесті «The Inconvenient Truth» (Незручна Правда) відповідальними за погіршення екологічної ситуації (забруднення води, нестачі ресурсів, неадекватної переробки, неконтрольованого розростання міст та надмірного споживання) та наближення глобальної екологічної катастрофи, покладає на мігрантів: «наш спосіб життя руйнує довкілля нашої країни. Знищення навколишнього середовища створює величезний тягар для майбутніх поколінь. ... навколишнє середовище погіршується 3 кожним роком. ... наступний логічний крок - зменшення кількості людей в Америці, які використовують ресурси. Якщо ми зможемо позбутися достатньої кількості людей, то наш спосіб життя може стати більш сталим» (Grabancijaš, 2019) - 3 серпня 2019 у м. Ель-Пасо (США, Техас) П. Крузіус здійснив озброєний напад, в наслідок якого загинуло 22 людини, 24 поранено.

Другий фактор - соціально-політичний: розчарування в політичних інститутах держави та діяльності міжнародних екологічних організацій критика держави та їі інститутів (політичних лідерів, політичних партій, уряду), звинувачення в корумпованості, некомпетентності та неефективності екологічної політики, недотримання норм екологічного законодавства, незадовільна оцінка діяльності міжнародних екологічних організацій (звинувачення в надмірному бюрократизмі, нецільовому використанні коштів, корупційних зв’язках 3 керівництвом корпорацій тощо), - все це привело до дискредитації політичних інститутів та міжнародних екологічних організація, та пошуку екоактивістами альтернативних шляхів до вирішення екологічних проблем, так «на зміну «атрофованим зеленим політикам» 3'явилися екотерористи» (Толстоухов, 2006). Згідно з дослідженням еволюції екологічного руху, виникнення екологічного радикалізму та екологічного 
тероризму відбувалось паралельно процесам інтеграції екологічної проблематики в політику, - «відбувається поляризація у ставленні до захисту природного середовища. Одні 3 них (зелені) йдуть у тихі кабінети 3 кондиціонерами, тоді як інші (екорадикали) підкладають бомби під екскаватори, стріляють 3 вогнепальної зброї, тобто використовують терористичні методи боротьби» (Толстоухов, 2006). Досліджуючи витоки екологічного тероризму, слід відзначите наступне, і що вкрай важливо, в контексті даного дослідження, - на момент входження екоактивістів в політичний простір, вони представляли ліві ідеологічні течії, але «на шляху від позапарламентської опозиції до урядових коаліцій весь зелений рух зміщався з лівого флангу до центра політичного спектра» (Толстоухов, 2006), надалі ж «ми побачили драматичні зміни патерну того, що визначається як екологічний тероризм - замість традиційних лівих активістів, його провідниками раптом виступили активісти ультра-праві» (Костюченко, 2019).

Деякий час екоактивісти переважно утримувались від насильницьких акцій, обмежуючись теоретичною риторикою, нехай навіть й вкрай радикального змісту, проте, 3 погіршенням екологічної ситуації та недостатніми зрушенням у вирішенні екологічних проблем з боку політиків (ігнорування або зволікання 3 визначенням стратегії державної екологічної політики, «паразитарство» на екологічній тематиці, корупція та спекуляції 3 екологічним законодавством тощо) - вдались до силових засобів ведення екологічної війни, за таких умов, відбувалось становлення екологічних терористичних організацій: Глибинний Екологічний Супротив (Deep Green Resistance), Хантінгдонске товариство по боротьбі з жорстоким поводженням 3 тваринами (Stop Huntingdon Animal Cruelty), Фронт 3 визволення тварин (Animal Liberation Front) та Фронт з визволення Землі (Earth Liberation Front), «Земля перш за все!» (Earth Above All), «Морські пастухи» (Sea Shepherds) та ін. Так, екологічна терористична організація «Фронт звільнення тварин» (Animal Liberation Front) оголосила про ведення війни - «Війни тривалої, важкої, кривавої» (Animal Liberation Front), активісти цих організацій 
практикують радикальну тактику прояву своїх поглядів: підпал будівельної техніки, підрив ЛЕП та інші терористичні дії. Протягом останніх років щорічно відбувається по кілька десятків насильницьких акцій еко-терористів в усьому світі, «і лише на території США збитки від актів саботажу та диверсій, вчинених представниками еко-феміністичних та еко-анархічних рухів складають близько 40 мільйонів доларів на рік. Зазвичай ці акти спрямовані проти об’єктів інфраструктури, бізнесу та технологічних лабораторій, і не мають жертв, хоча бувають і винятки. Наприклад, відомим еко-терорист Тед «Унабомбер» Качинський, який в період 31976 до 1995 , розсилаючи поштою бомби вченим та підприємцям, розробникам та розповсюджувачам комп'ютерних, авіаційних та природо ресурсних технологій, вчинив 16 підривів, вбивши 3 та поранивши 23 особи» (Костюченко, 2019).

Нове покоління екотерористів, яке сповідує крайні праві погляди, вирізняється антигуманізмом та екологічним екстремізмом, так, зокрема «Праві енвіронменталісти, прихильники теорії «глибинної екології», таки як Савітрі Деві, Джон М'юр, Пентті Лінкола, Дейв Формен чи Ален де Бенуа, взагалі дегуманізують людину, зводячи іï до одного з біологічних видів на планеті, обмежують можливості прогресу i, наділяючи природу сакральною сутністю, зводять розвиток людства до внутрішньовидової боротьби за виживання в умовах обмежених ресурсів та територій. Радикально праві політичні сили, які взагалі відмовляють людині в правах поза межами визначених структур i iєрархій, наприклад, контрольованої державою тоталітарної спільноти, не лише вимагають від громадян жертвувати своїми інтересами заради органічної цілісності сакралізованої природи, але і наполягають на необхідності боротьби з представниками інших спільнот за обмежені ресурси своєї території» (Костюченко, 2019).

Висновки i перспективи подальших досліджень. Екологічний тероризм, який, на думку провідних теоретиків сучасності - П. Глейка, М. Крайтона, Д. Ліддіка, Д. Шварца, Т. Шеффілда, К.Ф. Шлейсснера є більш 
загрозливим суспільно-політичним явищем ніж інші види терору (оскільки збитки не обмежуються самим актом насилля-терору, а призводять до довгострокових і широкомасштабних наслідків для значної частини насилля) та прогнозують тенденцію до зростання ризиків екологічного тероризму у XXI столітті, акцентуючи на особливій вразливості до проявів екологічного тероризму тих регіонів світу, які зазнають найбільших руйнувань від кліматично-екологічних трансформацій, що призведе до поглиблення наявних та спровокує нові «екологічні кризи», - отже, спираючи на вище зазначене, очевидним стає пріоритезація теоретичних розвідок екологічного радикалізму та екологічного тероризму в сучасному науковому просторі стає очевидною необхідністю.

\section{ЛІТЕРАТУРА}

1. Бек, У., 2000. Общество риска. На пути к другому модерну. Москва: ПрогрессТрадиция.

2. Горохова, Л., 2010. Проблема існування сучасної людини крізь призму екзистенціалу страху. Гілея, 38, с. 252-257.

3. Костюченко, Ю., 2019. Зміни, які з нами відбуваються, або Нові обличчя екотероризму. [online] (Останнє оновлення 8 Серпень 2019) Доступно: https://day.kyiv.ua/uk/blog/suspilstvo/zminy-yaki-z-namy-vidbuvayutsya-abo-novioblychchya-eko-teroryzmu [Дата звернення 10 Серпень 2019].

4. Курняк, Л. М., 2006. Екологічна культура: поняття і реальність. Вища освіта України, 3, с. 32-37.

5. Машков, О. та Мамчур, Ю., 2018. Загроза національні безпеці: екологічний тероризм, як сучасний виклик суспільству. Науковий часопис Академії нащіональної безпеки, 1(17), с. 8-21.

6. Стасюк, В., 2013. Поняття страху та його види: спроба детермінації. Вісник Національного університету оборони Украӥни, 3 (34), с. 312-315.

7. Толстоухов, А., 2006. Еко-майбутнє починається з «Еко+25\%». Дзеркало тижня, 27 Січня - 3 Лютого. [online] Доступно: https://dt.ua/ENVIRONMENT/ekomaybutne_pochinaetsya_z_eko25.html [Дата звернення 30 Червень 2019].

8. Уилсон, Э., 2017. Будущеее Земли. Наша Планета в борьбе за жизнь. Перевод с английского С. Чернин. Москва: Альпина нон-фикшн.

9. Animal Liberation Front, 2019. [online] Available at: https://animalliberationfrontline.com/ [Accessed 18 July 2019].

10. Gleick, P. H., 2006. Water and terrorism. Water Policy, [online] 8 (6) Available at: https://iwaponline.com/wp/article-abstract/8/6/481/20296/Water-andterrorism?redirectedFrom=fulltext [Accessed 5 July 2019]. 
11. MilneNews, 2019. The Great Replacement. [online] Available at: https://www.hollywoodlanews.com/wp-content/uploads/2019/03/The-Great-ReplacementNew-Zealand-Shooter.pdf [Accessed 15 July 2019].

12. Grabancijaš, 2019. Patrick Crusius Manifesto: The Inconvenient Truth. [online] Available at: https://grabancijas.com/patrick-crusius-manifesto-the-inconvenient-truth/ [Accessed 5 August 2019].

\section{Інформація про автора}

Калюжна Юлія Іванівна - кандидат політичних наук, викладач кафедри політології, соціології і культурології Харківського національного педагогічного університету імені Г.С. Сковороди; e-mail: kaliuzhna.yulia@gmail.com; ORCID: https://orcid.org/0000-00027344-410X.

Стаття надійшла до редакції: 04.11.2019 р. $\quad$ Прийнята до друку: 21.11.2019 р. 